\title{
MENINGKATKAN KEMAMPUAN KOMUNIKASI MATEMATIKA PESERTA DIDIK KELAS VIII B MTS N KUDUS MELALUI MODEL COOPERATIVE LEARNING TIPE JIGSAW BERBANTUAN KARTU MASALAH MATERI KUBUS DAN BALOK
}

Oleh :Eka Zuliana *)

Abstract

Before classroom action research was done, mathematical communication ability of the students at VIII B MTs N Kudus is not quite sufficient. This condition was caused by some factors, they are : the learning model was still convensional, where the teacher explained the definition or theorem orally so that the learning process at class was very bored, then the teacher gave an example and after that teacher gave some questions as exercises, the teacher also do not pay attention to mathematical communication ability so that students were affraid to ask and can not explain their idea, the students just memorize and remember their knowledge without learning experience.

Based on this condition, classroom action research is done. JIGSAW model by using Kartu Masalah (Kartu Masalah Problem Card) is a cooperative learning model consists of 4-5 students, every member of domain group has responsibility to solve the problem given through (Kartu Masalah Problem Card). The member of group who have same problems meet into a new group which called expert group then discuss the problem. From expert group the member of group come back to their domain group and explain the solution to another member. After that they must explain and present their solution in front of the class. in the last step the teacher give a quiz and give award.

This research was conducting in two cycles with taking some data through observation and tes. The average of mathematical communication ability test score was increased in every cycle, from the first cycle got 82,68 then was increased into 87,03 at second cycle. The average of mathematical communication activity score was increased from 2,13 in the first cycle to 3,20 at second cycle. And the average of learning management process score was increased from 2,92 to 3,24. Based on the result could be concluded that JIGSAW model by using (Kartu Masalah Problem Card) could improve the student mathematical communication ability of VIII B MTs N Kudus.

Keyword : cooperative learning model type JIGSAW, (kartu masalah problem card), mathematical communication ability.

\section{A. PENDAHULUAN}

\section{Latar Belakang}

Masalah utama dalam pembelajaran pada pendidikan formal (sekolah) adalah masih rendahnya daya serap peserta didik. Begitu juga dalam pembelajaran matematika. Sebuah laporan dalam studi TIMSS (Trends in International Mathematics and Science Study) tahun 2007 menyatakan bahwa rata-rata skor matematika peserta didik tingkat 8 di Indonesia berada di bawah rata-rata skor internasional dan berada pada ranking 36 dari 48 negara. Relevan dengan pernyataan tersebut Program for International Student Assesment (PISA) tahun 2006 menyatakan bahwa kemampuan 
peserta didik Indonesia dalam matematika memiliki rata-rata yang rendah pula. Dari 57 negara, Indonesia berada pada urutan 50.

Proses pembelajaran hingga dewasa ini masih memberikan dominasi guru dan kurang memberikan akses bagi peserta didik untuk berkembang secara mandiri melalui penemuan dalam proses berpikirnya (Trianto, 2009:3). Dalam mengajarkan matematika, pembelajaran di kelas hampir selalu dilaksanakan secara konvensional dengan urutan sajian: (1) diajarkan teori/definisi/teorema melalui pemberitahuan, (2) diberikan dan dibahas contoh-contoh, kemudian (3) diberikan latihan soal. Akibatnya, sampai saat ini kualitas pembelajaran matematika di Indonesia masih rendah. Schoenfeld (2001) menyatakan bahwa pengajaran matematika secara konvensional mengakibatkan peserta didik hanya bekerja secara prosedural dan memahami matematika tanpa penalaran. Kondisi ini melahirkan anggapan bagi peserta didik bahwa belajar matematika tidak lebih dari sekedar mengingat.

(Soedjadi, 1999:1) menyatakan bahwa perkembangan intelektual peserta didik umumnya bergerak dari konkrit ke abstrak, kiranya urutan penyajian dalam pembelajaran matematika tersebut di atas kurang tepat. Sehingga perlu dipikirkan secara mendalam tentang urutan sajian yang sesuai dengan perkembangan kognitif peserta didik. Di samping itu, selama ini guru cenderung mengajarkan matematika secara simbolis/abstrak yang bertentangan dengan perkembangan kognitif peserta didik dan kurang memanfaatkan lingkungan peserta didik sebagai sumber belajar. Perhatian guru lebih terpusat kepada hasil belajar, sehingga kurang memperhatikan proses belajar peserta didik. Untuk mengejar target kurikulum, guru tidak memberikan waktu yang cukup kepada peserta didik untuk terlibat secara aktif dalam pembelajaran. Akibatnya guru yang aktif dalam pembelajaran, sedangkan peserta didik menjadi pendengar dan penerima informasi (pengetahuan) dari guru secara pasif.

Guru dalam pembelajaran juga sering melupakan kemampuan-kemampuan matematika yang seharusnya dimiliki peserta didik. Menurut Kwang (2002) dalam pendidikan matematika, yang kita perhatikan adalah bahwa peserta didik seharusnya memperoleh kemampuan atau teknik yang kita identifikasi sebagai doing mathematics atau berpikir matematis. Kemampuan-kemampuan matematika sesuai dengan yang disebutkan NCTM (2000) adalah problem solving (kemampuan pemecahan masalah), reasoning and proof (kemampuan penalaran), communication (kemampuan komunikasi), connection (kemampuan koneksi), dan representasi (kemampuan representasi). 
Komunikasi matematika adalah suatu peristiwa saling hubungan atau dialog yang terjadi di dalam lingkungan kelas sehingga terjadi pengalihan pesan, pesan yang dialihkan berisi tentang materi matematika yang dipelajari di kelas. Pihak yang terlibat dalam peristiwa komunikasi di lingkungan kelas adalah guru dan peserta didik, sedangkan cara pengalihan pesan dapat secara lisan maupun tertulis (Asikin, 2001:1). Baroody dalam Asikin (2001) juga menyebutkan bahwa pada pembelajaran matematika dengan menggunakan pendekatan tradisional, komunikasi masih merupakan largely a one way affair. Komunikasi peserta didik masih sangat terbatas hanya pada jawaban verbal yang pendek atas berbagai pertanyaan yang diajukan oleh guru, kemampuan serta aktivitas dalam mengomunikasikan ide-ide matematikanya masih kurang.

Depdiknas (2006) menyebutkan bahwa Geometri merupakan penyumbang materi terbesar yakni sekitar $40 \%$ dari seluruh materi pokok matematika di SMP/MTs. Dengan kata lain geometri memiliki kedudukan yang esensial dalam kurikulum. Kedudukan geometri yang sedemikian esensial tidak lantas membuat pembelajaran geometri dapat dikatakan "lebih baik" dibandingkan pembelajaran matematika pada umumnya. Penyebab lemahnya penguasaan konsep geometri adalah karena dalam pembelajaran geometri tidak mempertimbangkan tingkat perkembangan berpikir peserta didik (Asaniah, 2004:2). Meskipun benda-benda konkret yang memuat bentuk dan konsep geometri banyak ditemui dalam kehidupan sehari-hari, namun realita di lapangan justru menunjukkan pembelajaran geometri masih memerlukan perhatian yang serius termasuk materi kubus dan balok.

Secara khusus peneliti mengamati pembelajaran geometri materi kubus dan balok yang ada di MTs N Kudus. Berdasarkan pengamatan peneliti kenyataan di lapangan menunjukkan bahwa kemampuan komunikasi matematika peserta didik masih terhitung kurang, ketuntasan belajar peserta didik juga masih kurang, ketuntasan belajar klasikal hanya mencapai $60 \%$. Hal ini disebabkan pembelajaran matematika masih terpengaruh oleh paradigma lama yang menempatkan guru sebagai pusat pembelajaran. Dalam proses pembelajaran peserta didik hanya mencatat dan mendengarkan konsep-konsep abstrak, diberikan contoh dan latihan soal, serta kurang dapat mengkritisi arti konsep tersebut.

Seorang guru harus dapat menjadi desainer yang mengajarkan teori dan mengimplementasikan teori tersebut kepada peserta didik dalam pembelajaran untuk mencapai tujuan pembelajaran (Joyce dan Weil, 1994:34). Untuk memecahkan masalah yang ada dalam pembelajaran matematika khususnya untuk meningkatkan 
kemampuan komunikasi matematika peserta didik diperlukan suatu strategi belajar yang efektif dan efisien. Oleh karena itu, diperlukan adanya pemilihan suatu model pembelajaran yang tepat dalam mendukung perencanaan strategi mengajar yang diterapkan untuk menyampaikan materi bahan ajar kepada peserta didik agar dapat memberikan iklim kondusif dalam perkembangan daya nalar, meningkatkan keaktifan dan kreatifitas peserta didik serta kemampuan komunikasinya. Salah satu strategi pemecahan masalah tersebut adalah dengan menggunakan model pembelajaran yang berpusat pada peserta didik yaitu model cooperative learning. Salah satu aspek penting dalam cooperative learning adalah bahwa selain model itu membantu meningkatkan perilaku kooperatif dan hubungan kelompok yang lebih baik diantara peserta didik, pada saat yang sama ia juga membantu peserta didik dalam pembelajaran akademiknya (Arends 2008: 12). cooperative learning adalah salah satu model pembelajaran luar biasa dan mempunyai teori, riset, dan praktik dalam pendidikan (Johnson et.al : 2000).

Model cooperative learning yang bisa dijadikan alternatif pembelajaran di kelas adalah model cooperative learning tipe JIGSAW. cooperative learning tipe JIGSAW didesain untuk meningkatkan rasa tanggung jawab peserta didik terhadap pembelajarannya sendiri dan juga pembelajaran orang lain. Peserta didik tidak hanya mempelajari materi yang diberikan, tetapi mereka juga harus siap memberikan dan mengajarkan materi tersebut pada anggota kelompoknya. Slavin (2010) menyatakan model cooperative learning tipe JIGSAW adalah salah satu tipe model pembelajaran kooperatif yang terdiri dari tim-tim belajar yang heterogen beranggotakan 4-5 orang peserta didik dan setiap peserta didik bertanggung jawab atas penguasaan bagian materi belajar dan mampu mengajarkan bagian materi tersebut kepada anggota tim yang lain, dan di akhir pembelajaran peserta didik mengerjakan kuis.

Anitah (2010) menyatakan pemilihan media pembelajaran yang tepat juga merupakan faktor penting dalam proses pembelajaran. Untuk itu, agar pembelajaran berlangsung lebih menarik, digunakan juga media pembelajaran. Pembelajaran akan menarik dan mudah dipahami oleh peserta didik apabila guru merancang media pembelajaran secara cermat dan tepat, serta dapat menggunakan media pembelajaran tersebut sesuai dengan fungsinya. Kartu masalah adalah salah satu media yang dapat digunakan. Dalam pembelajaran, kartu masalah digunakan sebagai aktivitas kelanjutan bagi peserta didik dalam pembelajaran yang diberikan sebagai tugas kelompok yang harus diselesaikan dan dipresentasikan solusi pemecahannya. Dengan JIGSAW berbantuan kartu masalah ini diharapkan peserta didik dapat tertarik, aktif dan lebih 
berani untuk mengemukakan pendapat atau ide pada saat pembelajaran berlangsung, sehingga dapat meningkatkan kemampuan komunikasi matematika peserta didik di dalam kelas.

Sehubungan dengan rendahnya kemampuan komunikasi matematika peserta didik kelas VIII B MTs N Kudus ini, penulis melakukan penelitian tindakan kelas dengan judul "Meningkatkan Kemampuan Komunikasi Matematika Peserta Didik Kelas VIII B MTs N Kudus melalui Model Cooperative Learning tipe JIGSAW Berbantuan Kartu Masalah Materi Kubus dan Balok”.

\section{Rumusan Masalah}

Masalah pokok yang dirumuskan dalam penelitian ini adalah "Apakah pembelajaran matematika dengan model cooperative learning tipe JIGSAW berbantuan Kartu Masalah dapat meningkatkan kemampuan komunikasi matematika peserta didik kelas VIII B MTs N Kudus pada materi kubus dan balok?”.

\section{Tujuan Penelitian}

Tujuan penelitian ini adalah untuk mengetahui apakah pembelajaran matematika dengan model cooperative learning tipe JIGSAW berbantuan kartu masalah dapat meningkatkan kemampuan komunikasi matematika peserta didik kelas VIII B MTs N Kudus pada materi kubus dan balok.

\section{B. KERANGKA TEORITIS DAN HIPOTESIS TINDAKAN}

\section{Kemampuan Komunikasi Matematika}

Komunikasi (secara konseptual) yaitu memberitahukan dan menyebarkan berita, pengetahuan, pikiran-pikiran dan nilai-nilai dengan maksud untuk menggugah partisipasi agar hal-hal yang diberitahukan menjadi milik bersama. Secara umum komunikasi mengandung pengertian memberikan informasi, pesan, gagasan, ide, pikiran, perasaan kepada orang lain dengan maksud agar orang lain berpartisipasi, yang pada akhirnya informasi, pesan, gagasan, ide, pikiran, perasaan tersebut menjadi milik bersama antara komunikator (sumber) dan komunikan (penerima) (Soeharto, 1995:11).

Komunikasi adalah suatu proses penyampaian pesan oleh sumber melalui saluransaluran tertentu kepada penerima atau "receiver" (Suparno, 2001:135). Dalam setiap peristiwa komunikasi terkandung sejumlah unsur diantaranya pesan yang disampaikan, pihak-pihak yang terlibat dalam peristiwa komunikasi tersebut, serta 
cara pengalihan/penyampaian pesan serta teknologi yang dijadikan sarana. Pesanpesan itu dapat berbentuk lisan maupun tulisan, dapat bersifat verbal maupun non verbal, dalam arti bahwa simbol-simbol yang disepakati tidak diucapkan tetapi disampaikan melalui cara/alat selain kata-kata dan mempunyai makna yang dipahami oleh keduanya. Untuk mencapai interaksi dalam belajar mengajar perlu adanya komunikasi yang jelas antara guru dengan peserta didik. Sering dijumpai kegagalan pembelajaran disebabkan lemahnya komunikasi antara guru dan peserta didik. Jika para peserta didik hanya pasif dalam pembelajaran akan mengakibatkan guru tidak dapat menetahui tingkat kesukaran yang dihadapi masing-masing peserta didik Untuk itulah guru perlu mengembangkan pola komunikasi yang efektif dalam proses pembelajaran.

Komunikasi dalam pembelajaran dapat diartikan sebagai suatu peristiwa saling hubungan/dialog yang terjadi dalam suatu lingkungan kelas dimana terjadi pengalihan pesan dan makna budaya (Asikin, 2001:1). Komunikasi matematika adalah suatu peristiwa saling hubungan atau dialog yang terjadi dalam lingkungan kelas sehingga terjadi pengalihan pesan, pesan yang dialihkan berisi tentang materi matematika yang dipelajari dikelas secara evaluasi maupun lisan (Asikin, 2001). Pihak yang terlibat dalam komunikasi di kelas adalah guru dan peserta didik. Komunikasi matematika adalah proses menyatakan dan menafsirkan gagasaan matematika secara lisan, evaluasi, atau mendemonstrasikannya (Tim PPPG Matematika, 2005:58).

Kemampuan komunikasi matematika adalah kemampuan atau kesanggupan peserta didik dalam mengalihkan pesan yang berupa materi matematika, menyatakan dan menafsirkan gagasaan matematika secara lisan, evaluasi, atau mendemonstrasikannya kepada guru dan peserta didik lainnya.

Indikator kemampuan komunikasi matematika dalam Sumarmo (2003:4) adalah sebagai berikut.

a. Menghubungkan benda nyata, gambar, dan diagram ke dalam ide matematika.

Contohnya adalah peserta didik mampu memecahkan masalah matematika yang sedang dihadapi melalui benda nyata yang terdapat disekitarnya dan kaitannya dengan materi yang sedang dipelajari.

b. Menjelaskan ide, situasi, dan relasi matematika secara lisan atau tulisan, dengan benda nyata, gambar, grafik, dan aljabar. 
Contohnya adalah peserta didik dapat mengingat kembali pengalaman yang pernah dialaminya untuk memecahkan permasalahan matematika yang sedang dihadapi dengan menggunakan gambar.

c. Menyatakan peristiwa sehari-hari dalam bahasa/simbol matematika.

Contohnya adalah peserta didik dapat membuat soal cerita dengan kalimat yang baik tentang kaitannya antara materi yang sedang dipelajari dengan peristiwa di sekitarnya.

d. Mendengarkan, berdiskusi, dan menulis tentang matematika.

Contohnya adalah peserta didik dapat menuliskan kembali dengan benar kesimpulan dari materi yang telah dipelajari dengan menggunakan bahasa mereka sendiri.

e. Membaca presentasi matematika evaluasi dan menyusun pertanyaan yang relevan.

Contohnya adalah peserta didik dapat membuktikan permasalahan matematika tentang materi yang sedang dipelajari.

f. Menyusun argumen, merumuskan definisi, dan generalisasi.

Contohnya adalah peserta didik dapat memberikan contoh permasalahan matematika yang sedang terjadi di daerahnya dan berhubungan dengan materi yang telah dipelajari kemudian menuliskannya dalam bentuk soal cerita.

(Cai, 1996; Baroody, 1993; Miriam, dkk, 2000; Karen, dkk, 2000; Sandra, 1999; David, 2000; Pugalee, 2001; Knuth, 2001) dalam Asikin (2001) menyatakan komunikasi dalam matematika dapat membantu mempertajam cara berpikir peserta didik dan mempertajam kemampuan peserta didik dalam melihat berbagai keterkaitan materi matematika dan dapat merefleksikan pemahaman matematika para peserta didik, dapat mengorganisasikan dan mengkonsolidasikan pemikiran matematika peserta didik, untuk pengkontruksikan pengetahuan matematika, pengembangan pemecahan masalah, dan peningkatan penalaran, menumbuhkan rasa percaya diri, peningkatan ketrampilan sosial, serta menjadi alat yang sangat bermakna untuk membentuk komunitas matematika yang inklusif.

Komunitas matematika dimaknai sebagai suatu komunitas dalam kelas yang menggunakan matematika sebagai bahan/isi percakapan. Lauren (1999) dalam Asikin (2001) menyatakan percakapan yang produktif tentang matematika membuat peserta didik berkomunikasi dengan matematika sehingga membantu peserta didik untuk mulai berpikir secara matematis dan membangun secara benar keterkaitan matematis. 


\section{Model Cooperative Learning}

Model pembelajaran mempunyai empat ciri khusus yang tidak dipunyai oleh strategi atau metode tertentu, yaitu rasional teoritik yang logis, tujuan pembelajaran yang akan dicapai, tingkah laku mengajar yang diperlukan agar model tersebut dapat dilaksanakan secara berhasil, dan lingkungan belajar yang diperlukan agar tujuan pembelajaran itu dapat tercapai (Asikin, 2003:3).

Slavin (2010) menyatakan model cooperative learning merupakan sebuah model pembelajaran dengan menempatkan peserta didik di dalam kelompok kecil di mana peserta didik mengungkapkan ide gagasan mereka dan bekerja secara kolaboratif untuk menyelesaikan tugas yang diberikan oleh guru. Johnson, Johnson, dan Holubec (1994) menyatakan bahwa ada lima elemen penting dalam cooperative learning, yaitu:

a. Peserta didik saling memiliki ketergantungan yang positif di mana keberhasilan anggota yang satu juga merupakan keberhasilan anggota yang lainnya.

b. Peserta didik memiliki interaksi promotif : kerja kelompok dilakukan secara langsung dengan tatap muka dan saling menjelaskan satu dengan lainnya.

c. Peserta didik memiliki akuntabilitas individu : setiap anggota kelompok memiliki kontribusi belajar dalam kelompok, tidak ada satu pun anggota kelompok yang tidak memiliki andil dalam kelompok. Hal ini dapat dilihat dari hasil tes individu dan presentasi kelompok dengan jalan guru memanggil secara acak anggota kelompok untuk mempresentasikan hasil diskusi kelompok.

d. Peserta didik memiliki kemampuan interpersonal dan kemampuan berdiskusi dalam kelompok kecil. Di dalam kelompok harus terjadi komunikasi, kepercayaan, kepemimpinan, pengambilan keputusan, dan resonansi konflik.

e. Adanya proses pengolahan kelompok yang merefleksikan seberapa baik tim berfungsi dan bagaimana fungsi tim dapat semakin ditingkatkan.

Pada penelitian ini dalam rangka meningkatkan kemampuan komunikasi matematika peserta didik, peneliti menggunakan model cooperative learning tipe JIGSAW.

\section{JIGSAW}

Slavin (2010) menyatakan model cooperative learning tipe JIGSAW adalah salah satu tipe model pembelajaran kooperatif yang terdiri dari tim-tim belajar yang heterogen beranggotakan 4-5 orang peserta didik dan setiap peserta didik bertanggung jawab atas penguasaan bagian materi belajar dan mampu mengajarkan bagian materi tersebut kepada anggota tim yang lain, dan di akhir pembelajaran peserta didik mengerjakan kuis dan guru memberikan penghargaan kelompok. Dalam model 
cooperative learning tipe JIGSAW ini peserta didik dituntut aktif dalam menyampaikan dan mengkomunikasikan ide/gagasan yang dimiliki, dan menyelesaikan tugas secara berkelompok. Dengan adanya penghargaan kelompok di akhir pembelajaran, maka masing-masing peserta didik akan termotivasi untuk aktif dalam kelompok dan bekerja dalam kelompoknya dengan sebaik-baiknya untuk dapat menyumbangkan skor yang tinggi bagi kelompoknya.

Langkah-langkah pembelajaran cooperative learning tipe JIGSAW adalah sebagai berikut.

\begin{tabular}{|c|c|}
\hline Langkah & JIGSA W \\
\hline Pendahuluan & $\begin{array}{l}\text { 1) Review, apersepsi, motivasi. } \\
\text { 2) Menjelaskan pada peserta didik tujuan dan model pembelajaran } \\
\text { yang dipakai. } \\
\text { 3) Pembentukan kelompok. Setiap kelompok terdiri dari } 4-5 \\
\text { peserta didik dengan kemampuan yang heterogen. } \\
\text { 4) Pembagian materi/masalah pada setiap anggota kelompok. }\end{array}$ \\
\hline $\begin{array}{c}2 \\
\text { Penguasaan }\end{array}$ & $\begin{array}{l}\text { 1) Peserta didik dengan materi/masalah yang sama bergabung } \\
\text { dalam kelompok ahli dan berusaha menguasai materi sesuai } \\
\text { dengan soal yang diterima. } \\
\text { 2) Guru memberikan bimbingan. }\end{array}$ \\
\hline $\begin{array}{c}3 \\
\text { Penularan }\end{array}$ & $\begin{array}{l}\text { 1) Setiap peserta didik kembali kekelompok asalnya. } \\
\text { 2) Setiap peserta didik dalam kelompok saling menularkan dan } \\
\text { menerima materi/solusi masalah dari peserta didik lain. } \\
\text { 3) Terjadi diskusi antar peserta didik dalam kelompok asal. } \\
\text { 4) Dari diskusi, peserta didik memperoleh penyelesaian masalah } \\
\text { yang diberikan guru. }\end{array}$ \\
\hline $\begin{array}{c}4 \\
\text { Penutup }\end{array}$ & $\begin{array}{l}\text { 1) Guru bersama peserta didik membahas kesimpulan } \\
\text { materi/masalah yang diberikan. } \\
\text { 2) Pada akhir pembelajaran diadakan kuis yang bersifat individual, } \\
\text { diantara peserta didik tidak boleh saling membantu. } \\
\text { 3) Skor kuis dari masing-masing kelompok asal saling } \\
\text { diperbandingkan untuk menentukan kelompok asal mana yang } \\
\text { paling berhasil. } \\
\text { 4) Kelompok asal yang paling berhasil, selanjutnya diberikan } \\
\text { penghargaan atas keberhasilannya. }\end{array}$ \\
\hline
\end{tabular}

\section{Kartu Masalah}

Kartu masalah merupakan aplikasi masalah dari materi pembelajaran yang diberikan. Dalam pembelajaran, kartu masalah digunakan sebagai aktivitas kelanjutan bagi peserta didik dalam pembelajaran yang diberikan sebagai tugas kelompok yang harus diselesaikan dan dipresentasikan solusi pemecahannya. 


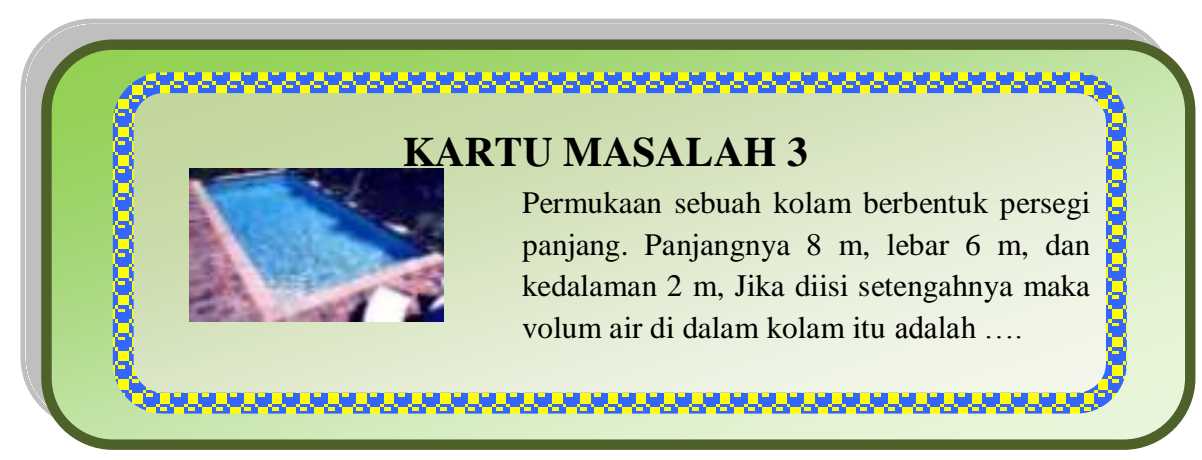

Gambar 1. Contoh Kartu masalah

\section{Penelitian yang Relevan}

Beberapa penelitian yang relevan dengan penelitian ini telah dilakukan oleh para peneliti sebelumnya. Hasil penelitian Haetami, dkk (2008) menunjukkan model pembelajaran kooperatif tipe JIGSAW dapat meningkatkan hasil belajar dan aktivitas peserta didik. Penelitian Wijayanti (2009) menunjukkan bahwa pembelajaran kooperatif tipe JIGSAW dapat meningkatkan hasil belajar mahasiswa pada mata kuliah aljabar linier elementer 2, dan hasil penelitian Budiarsih (2007) menunjukkan model pembelajaran kooperatif tipe JIGSAW efektif untuk mengajarkan materi geometri.

\section{Kerangka Berpikir}

Pembelajaran matematika materi kubus dan balok diajarkan di SMP/MTs pada semester genap, dengan standar kompetensi: Memahami sifat-sifat kubus, balok, prisma, limas, dan bagian-bagiannya, serta menentukan ukurannya. Pembelajaran matematika dengan model cooperative learning tipe JIGSAW berbantuan kartu masalah pada materi kubus dan balok adalah pembelajaran matematika dengan suatu model pembelajaran kooperatif dengan strategi kelompok belajar yang terdiri dari 4-5 peserta didik yang dibentuk secara heterogen. Setiap peserta didik bertanggung jawab atas penguasaan bagian materi belajar dan mampu mengajarkan bagian materi tersebut kepada anggota tim yang lain, dan di akhir pembelajaran peserta didik mengerjakan kuis dan guru memberikan penghargaan kelompok.

Peserta didik dalam pembelajaran ini dituntut aktif menyampaikan dan mengkomunikasikan ide/gagasan yang dimiliki, dan menyelesaikan tugas secara berkelompok. Didukung oleh kartu masalah yang menarik dan menantang, model pembelajaran ini mampu menuntut keterlibatan peserta didik secara aktif, kreatif, dan trampil dalam menyampaikan pendapat, mengemukakan ide/gagasan dalam menyelesaikan masalah, serta dengan adanya penghargaan kelompok di akhir 
pembelajaran, masing-masing peserta didik akan termotivasi untuk aktif dalam kelompok dan bekerja dalam kelompoknya dengan sebaik-baiknya untuk dapat menyumbangkan skor yang tinggi bagi kelompoknya. Kebebasan peserta didik dalam menyampaikan pendapat, mengkomunikasikan ide/gagasan mereka merupakan proses pembelajaran yang efektif. Semakin baik kemampuan komunikasi peserta didik, akan berdampak terhadap peningkatan hasil belajar peserta didik.

\section{Hipotesis Tindakan}

Berdasarkan beberapa teori pendukung dan kerangka berpikir di atas maka hipotesis dalam penelitian tindakan kelas ini adalah model cooperative learning tipe JIGSAW berbantuan kartu masalah dapat meningkatkan kemampuan komunikasi matematika peserta didik kelas VIII B MTs N Kudus pada materi Kubus dan Balok.

\section{METODOLOGI PENELITIAN}

\section{Lokasi Penelitian}

Penelitian tindakan kelas ini dilaksanakan di kelas VIII B MTs N Kudus.

\section{Subjek Penelitian}

Subjek dalam penelitian ini adalah peserta didik kelas VIII B MTs N Kudus semester dua yang berjumlah 40 orang peserta didik dengan fokus penelitian pada kemampuan komunikasi matematika peserta didik.

\section{Desain Penelitian}

Menurut Kurt Lewin, prosedur kerja dalam penelitian tindakan kelas terdiri atas empat komponen, yaitu perencanaan (planning), pelaksanaan (acting), pengamatan (observing), dan refleksi (reflecting). Hubungan keempat komponen tersebut dipandang sebagai satu siklus (Depdikbud, 1999:20). Prosedur kerja tersebut secara garis besar dapat digambarkan dalam gambar 2 sebagai berikut.

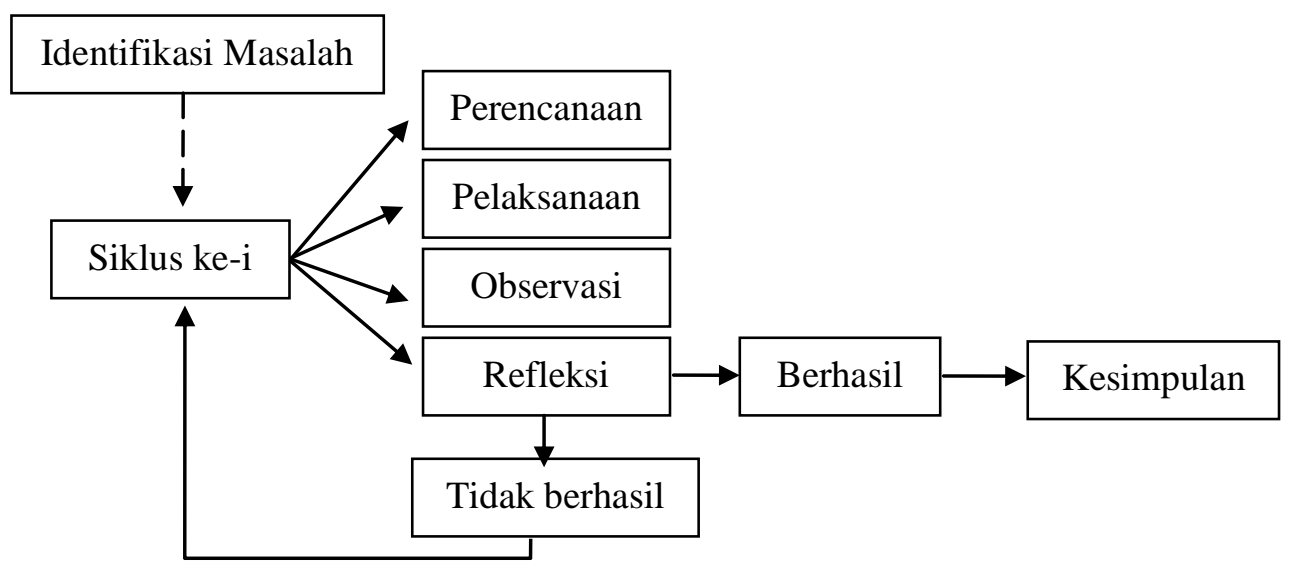

Gambar 2. Deskripsi pelaksanaan siklus 
Adapun gambaran rencana pelaksanaan setiap siklus adalah sebagai berikut:

a. Perencanaaan (planning)

Kegiatan dalam tahap perencanaan ini meliputi hal-hal sebagai berikut.

1) Studi pendahuluan terhadap kemampuan komunikasi matematika peserta didik.

2) Merencanakan pembelajaran dengan membuat Silabus, RPP, lembar konsep, membuat tugas rumah dan pembahasannya.

3) Membuat kisi-kisi, kartu masalah, dan pedoman penskoran kartu masalah.

4) Membuat kisi-kisi, soal, dan pedoman penskoran kuis.

5) Membuat kisi-kisi, soal, dan pedoman penskoran soal tes akhir siklus.

6) Membuat lembar pengamatan kemampuan komunikasi matematika peserta didik.

7) Peneliti dan teman sejawat membuat lembar pengamatan pengelolaan pembelajaran matematika dengan menggunakan model cooperative learning tipe JIGSAW berbantuan kartu masalah.

8) Merencanakan pembentukan kelompok heterogen.

b. Pelaksanaan/implementasi tindakan (acting)

Tahap pelaksanaan/implementasi tindakan merupakan tahap pelaksanaan proses pembelajaran di kelas. Pelaksanaan tindakan dilaksanakan dalam 3 kali pertemuan selama enam jam pelajaran (6x40 menit). Pertemuan pertama dimanfaatkan untuk proses pembelajaran berupa diskusi penemuan konsep, Pertemuan kedua digunakan untuk proses diskusi menyelesaikan masalah yang diambil dari kartu masalah, presentasi kelompok, dan diakhiri dengan kuis. Sebelum pembelajaran ditutup guru memberikan reward kepada kelompok super (skor perkembangan tertinggi). Sedangkan pertemuan ketiga digunakan untuk mengambil data tes akhir siklus.

c. Pengamatan (Observasi)

Observasi dilakukan oleh teman sejawat sebagi kolabolator. Lembar pengamatan digunakan untuk mengamati dan mengukur kemampuan komunikasi matematika peserta didik serta aktivitas peneliti pada saat proses pembelajaran berlangsung. Langkah selanjutnya adalah mengumpulkan data tingkat kemampuan komunikasi matematika peserta didik berdasarkan hasil tes di akhir siklus dan pelaksanaan tugas yang diberikan oleh peneliti. 
d. Refleksi

Refleksi merupakan analisis hasil observasi dan hasil tes. Refleksi dilaksanakan segera setelah tahap implementasi/tindakan dan observasi selesai. Pada tahap ini peneliti dan teman sejawat mendiskusikan hasil yang meliputi kelebihan dan kekurangan pada pembelajaran. Hasil refleksi ini akan digunakan sebagai perbaikan dalam pelaksanaan siklus berikutnya.

\section{Teknik Pengumpulan Data}

Berbagai data yang dikumpulkan dalam penelitian dan teknik pengambilan data tersebut dapat dilihat secara ringkas pada tabel 1 berikut.

Tabel 1. Teknik pengumpulan data

\begin{tabular}{|c|c|c|c|}
\hline No & Data & Alat / Instrumen & Metode / Prosedur \\
\hline 1 & $\begin{array}{l}\text { Nilai kemampuan komunikasi } \\
\text { matematika peserta didik }\end{array}$ & Tes & Tes akhir setiap siklus \\
\hline 2 & $\begin{array}{l}\text { Skor aktivitas komunikasi } \\
\text { matematika peserta didik }\end{array}$ & Lembar observasi & Pengamatan \\
\hline 3 & $\begin{array}{l}\text { Pengelolalan pembelajaran } \\
\text { oleh guru }\end{array}$ & Lembar observasi & Pengamatan \\
\hline 4 & $\begin{array}{l}\text { Refleksi dan sikap peserta } \\
\text { didik dalam pembelajaran }\end{array}$ & $\begin{array}{l}\text { Angket refleksi } \\
\text { peserta didik }\end{array}$ & $\begin{array}{l}\text { Penyebaran angket } \\
\text { kepada peserta didik }\end{array}$ \\
\hline
\end{tabular}

\section{Indikator Keberhasilan}

Indikator keberhasilan penelitian tindakan kelas ini adalah sebagai berikut.

a. Nilai rata-rata kelas untuk tes kemampuan komunikasi matematika peserta didik $\geq 70$ dengan persentase ketuntasan klasikal $\geq 75 \%$.

b. Skor rata-rata kemampuan komunikasi matematika peserta didik dalam pembelajaran $\geq 2,5$ yang diambil dengan menggunakan lembar pengamatan kemampuan komunikasi. Skor ini diperkuat dengan hal-hal sebagai berikut.

a. Tidak ada peserta didik pasif dalam kelompoknya.

b. Ada lebih dari 4 peserta didik yang berani bertanya kepada guru.

c. Ada lebih dari 4 peserta didik yang berani mendemonstrasikan.

c. Skor rata-rata kemampuan guru dalam kegiatan pembelajaran dengan menggunakan model cooperative learning tipe JIGSAW $\geq 2,5$ yang diambil dengan mengunakan lembar pengamatan pengelolaan pembelajaran. 


\section{HASIL PENELITIAN DAN PEMBAHASAN}

\section{Hasil Penelitian}

1) Hasil penelitian siklus 1

Penelitian pada siklus 1 diperoleh hasil berupa nilai rata-rata hasil tes kemampuan komunikasi matematika peserta didik, prosentase ketuntasan klasikal, skor pengelolaan pembelajaran, dan skor pengamatan aktivitas kemampuan komunikasi matematika peserta didik seperti pada tabel 2 berikut.

Tabel 2. Hasil penelitian siklus 1

\begin{tabular}{|c|l|c|c|}
\hline No & \multicolumn{1}{|c|}{ Data } & Hasil & Keterangan \\
\hline 1 & $\begin{array}{l}\text { Rata-rata tes kemampuan komunikasi } \\
\text { peserta didik }\end{array}$ & 82,68 & Tuntas \\
\hline 2 & Prosentase ketuntasan klasikal & $82,5 \%$ & Tuntas \\
\hline 3 & Pengelolaan pembelajaran & 2,92 & Baik (tuntas) \\
\hline 4 & $\begin{array}{l}\text { Aktivitas komunikasi matematika peserta } \\
\text { didik dalam pembelajaran }\end{array}$ & 2,13 & $\begin{array}{c}\text { Cukup baik } \\
\text { (belum tuntas) }\end{array}$ \\
\hline
\end{tabular}

Ditinjau dari beberapa aspek komunikasi matematika ada beberapa hal yang dapat dijadikan catatan untuk perbaikan, antara lain:

a) Kemampuan peserta didik dalam memberikan contoh yang lain masih sangat kurang, hal ini ditunjukkan dalam aspek ke-2 pada siklus 1 ini hanya memperoleh skor 1 .

b) Masih banyak peserta didik dalam kelompok yang pasif dalam mengerjakan tugas.

c) Peserta didik kurang aktif, masih terkesan malu dan belum berani secara keseluruhan mengeluarkan ide, pendapat dan gagasannya kepada teman, peneliti maupun guru. Peserta didik belum berani all out pada saat presentasi kelompok. Setiap akan maju mereka membutuhkan waktu lama untuk bernegosiasi dengan teman di kelompoknya dalam menentukan siapa yang akan mewakili mempresentasikan hasil kerja kelompoknya.

d) Peserta didik masih canggung karena baru pertama kali menerima pembelajaran dengan model cooperative learning tipe JIGSAW.

Hasil refleksi siklus 1 yang dilakukan, diperoleh kesimpulan bahwa pelaksanaan penelitian tindakan kelas pada siklus 1 belum mencapai indikator yang 
ditetapkan. Oleh karena itu perlu dilaksanakan siklus berikutnya yaitu siklus 2 dengan rencana perbaikan antara lain :

1) Perubahan kelompok

2) Meningkatkan jumlah peserta didik yang aktif dalam pembelajaran yaitu dengan cara meningkatkan keoptimalan kerja sama peserta didik dalam kelompok serta bimbingan yang lebih intensif

3) Peserta didik dimotivasi untuk lebih dapat mengungkapkan ide dan gagasan mereka.

2. Hasil penelitian siklus 2

Hasil penelitian pada siklus 2 secara ringkas dapat dilihat pada tabel 3 berikut.

Tabel 3. Hasil penelitian siklus 2

\begin{tabular}{|c|l|c|c|}
\hline No & \multicolumn{1}{|c|}{ Data } & Hasil & Keterangan \\
\hline 1 & $\begin{array}{l}\text { Rata-rata tes kemampuan komunikasi } \\
\text { peserta didik }\end{array}$ & 87,03 & Tuntas \\
\hline 2 & Prosentase ketuntasan klasikal & $90 \%$ & Tuntas \\
\hline 3 & Pengelolaan pembelajaran & 3,24 & Baik (tuntas) \\
\hline 4 & $\begin{array}{l}\text { Aktivitas komunikasi matematika peserta } \\
\text { didik dalam pembelajaran }\end{array}$ & 3,20 & Baik (tuntas) \\
\hline
\end{tabular}

Dari tabel tersebut terlihat bahwa seluruh indikator telah tuntas. Hasil penelitian pada tabel hasil penelitian siklus 2 diperkuat dengan :

a) Tidak ada peserta didik dalam kelompok yang pasif dalam mengerjakan tugas..

b) Ada lebih dari 4 peserta didik yang berani bertanya kepada peneliti/guru tentang materi yang sedang diajarkan.

c) Ada lebih dari 4 peserta didik yang berani maju ke depan mendemonstrasikan temuannya.

Refleksi siklus 2 dilaksanakan setelah berakhirnya pelaksanaan siklus 2. Dari hasil refleksi yang dilakukan, diperoleh kesimpulan bahwa pelaksanaan penelitian tindakan kelas telah mencapai indikator yang ditetapkan.

Pada siklus 2 ini juga diberikan angket kepada peserta didik. Angket ini digunakan untuk mengetahui sikap peserta didik terhadap pelajaran matematika, khususnya jika pada proses pembelajaran matematika menggunakan model cooperative learning tipe JIGSAW berbantuan kartu masalah. Analisis hasil angket refleksi pembelajaran secara ringkas adalah sebagai berikut: 
1. $100 \%$ peserta didik senang terhadap pembelajaran.

2. $97,5 \%$ peserta didik beranggapan pembelajaran tersebut dapat meningkatkan kerjasama kelompok.

3. $62,5 \%$ peserta didik beranggapan pembelajaran tersebut dapat membuat mereka lebih berani bertanya.

4. $80 \%$ peserta didik beranggapan pembelajaran tersebut membuat peserta didik lebih berani menanggapi pendapat teman mereka.

5. $87,5 \%$ peserta didik beranggapan pembelajaran tersebut membuat mereka mudah memahami materi yang diberikan.

6. $97,5 \%$ peserta didik beranggapan dengan kartu masalah yang diberikan mereka merasa lebih tertarik dan tertantang untuk mendiskusikan dan menyelesaikan soalsoal kubus dan balok.

7. $65 \%$ peserta didik termotivasi untuk belajar lebih giat dengan adanya model cooperative learning tipe JIGSAW.

8. $80 \%$ peserta didik termotivasi untuk belajar dengan adanya kartu masalah dan presentasi di depan kelas.

9. $75 \%$ peserta didik beranggapan bahwa penjelasan dari teman mereka membuat mereka lebih paham dengan materi yang diajarkan.

10. 67,5 \% peserta didik lebih berani tampil di depan kelas dengan adanya presentasi.

\section{Pembahasan}

Pelaksanaan dan pengelolaan pembelajaran matematika dengan model cooperative learning tipe JIGSAW berbantuan kartu masalah pada siklus 1 sudah baik dengan skor rata-rata sebesar 2,92. Skor rata-rata tes kemampuan komunikasi matematika peserta didik sebesar 82,68 dengan ketuntasan klasikal 82,5\%. Hal ini menunjukkan kemampuan kognitif peserta didik dalam mengkomunikasikan ide/gagasan ke dalam bahasa matematika sudah baik (tuntas). Namun berdasarkan hasil observasi dari lembar pengamatan aktivitas komunikasi matematika peserta didik diperoleh skor rata-rata sebesar 2,13. Hal ini menunjukkan aktivitas komunikasi matematika peserta didik masih perlu ditingkatkan karena belum tuntas.

Hal-hal tersebut menyebabkan siklus 1 belum berhasil sehingga penelitian dilanjutkan pada siklus 2. Pada siklus 2 peneliti berusaha lebih giat dan lebih sering lagi 
dalam memberikan motivasi dan semangat kepada peserta didik untuk lebih aktif dengan cara memberikan penghargaan nilai pada peserta didik yang selalu aktif dalam pembelajaran, lantang dalam presentasi, dan berani berpendapat. Sedangkan untuk meningkatkan keoptimalan kerja sama peserta didik dalam kelompok perlu diadakan perubahan dalam pembentukan kelompok. Dari hasil penelitian siklus 1 ini peneliti menyimpulkan bahwa peserta didik sebenarnya belum mampu mengkomunikasikan gagasannya lewat lisan, mereka masih belum berani dan malu jika diminta mengkomunikasikan gagasannya secara langsung lewat presentasi, hal ini disebabkan presentasi merupakan hal yang jarang dilakukan dalam pembelajaran.

Pada siklus 2 nilai rata-rata kemampuan komunikasi matematika peserta didik meningkat menjadi 87,03 dengan prosentase ketuntasan klasikal adalah 90\%, sehingga dapat disimpulkan bahwa nilai rata-rata kemampuan komunikasi matematika peserta didik pada siklus 2 sudah baik dan memenuhi indikator keberhasilan penelitian. Pelaksanaan dan pengelolaan pembelajaran matematika dengan model cooperative learning tipe JIGSAW pada siklus 2 sudah baik bahkan terjadi peningkatan menjadi 3,24 . Sedangkan berdasarkan hasil observasi dari lembar pengamatan kemampuan komunikasi matematika peserta didik diperoleh skor rata-rata sebesar 3,20. Ini juga menunjukkan terjadinya peningkatan skor aktivitas komunikasi matematika peserta didik. Sehingga semua indikator kinerja dalam penelitian ini sudah tercapai pada siklus 2. Secara lebih jelas, hasil analisis data disajikan dalam diagram sebagai berikut :

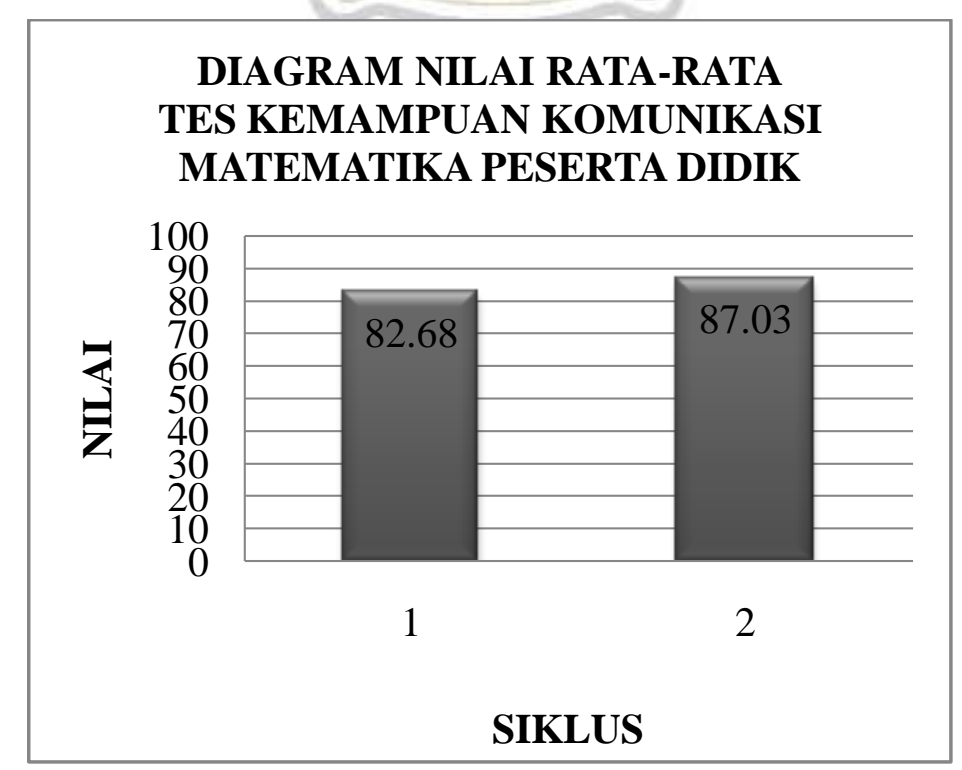

Gambar 3. Diagram nilai rata-rata tes kemampuan komunikasi matematika peserta didik selama proses pembelajaran. 


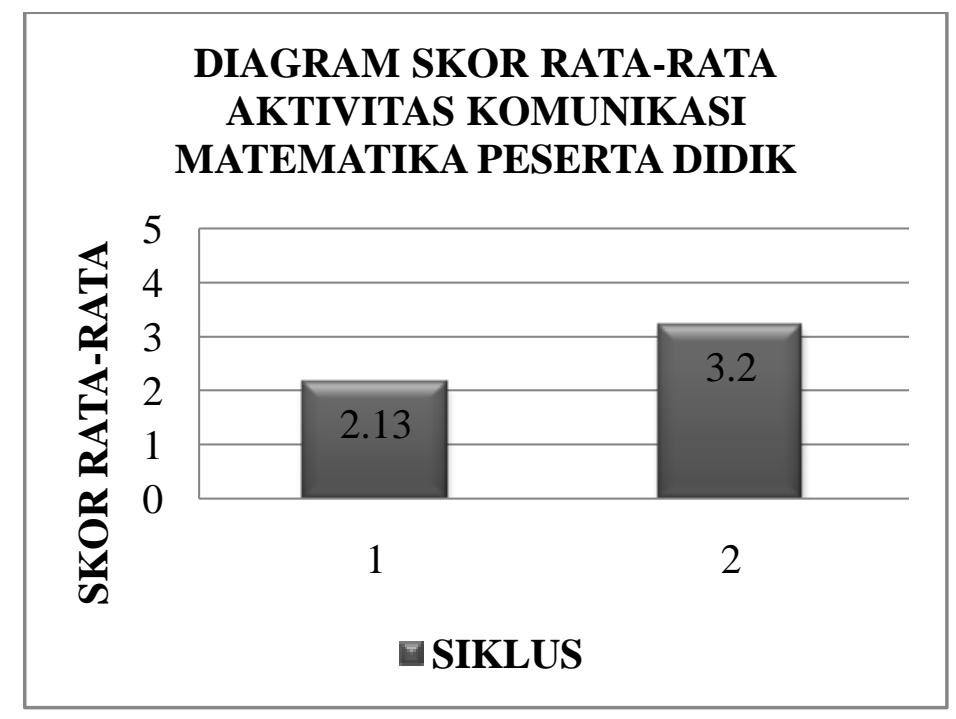

Gambar 4. Diagram skor rata-rata aktivitas komunikasi matematika peserta didik selama proses pembelajaran.

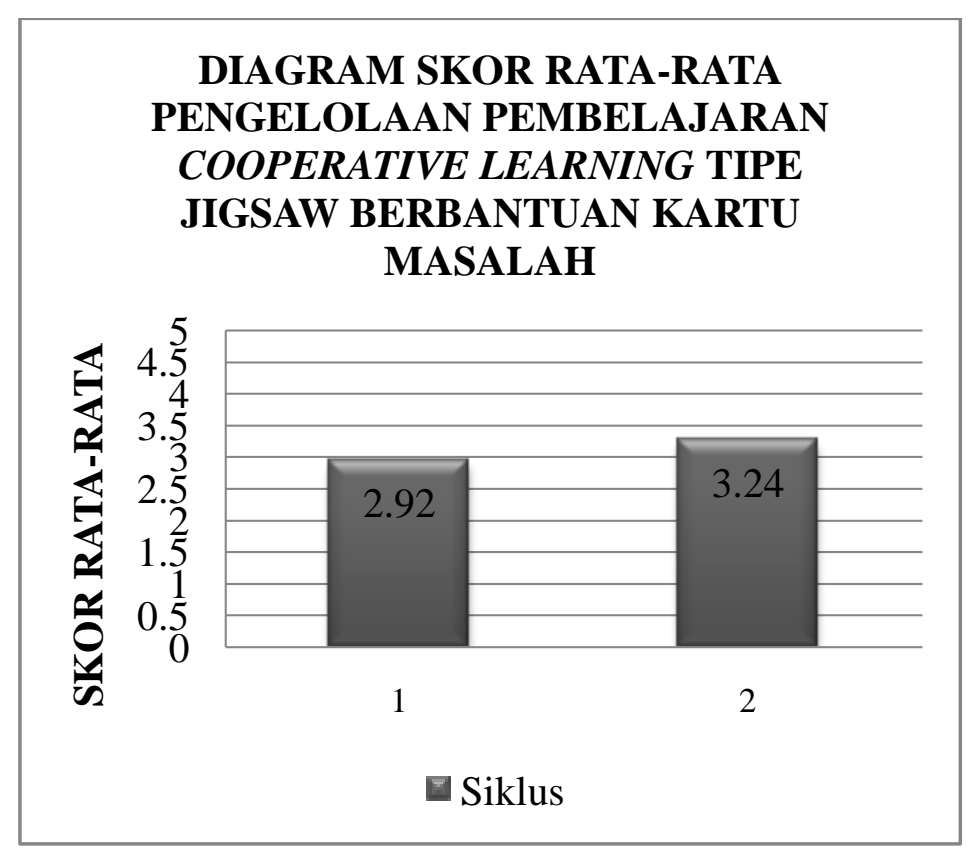

Gambar 5. Diagram skor rata-rata pengelolaan pembelajaran cooperative learning tipe JIGSAW berbantuan kartu masalah.

Paparan tersebut dapat dibawa pada suatu kesimpulan bahwa model cooperative learning tipe JIGSAW berbantuan kartu masalah dapat meningkatkan kemampuan komunikasi matematika peserta didik baik dari segi aktivitas di kelas maupun kemampuan peserta didik sendiri pada saat tes akhir setiap siklusnya. Kesimpulan ini diperkuat dengan angket yang memperlihatkan bahwa peserta didik merasa lebih baik dalam mengikuti pembelajaran matematika yang menggunakan model cooperative learning tipe JIGSAW berbantuan kartu masalah. 


\section{PENUTUP}

\section{Simpulan}

Simpulan dari penelitian ini adalah penerapan model cooperative learning tipe JIGSAW berbantuan kartu masalah yang telah dilaksanakan di kelas VIII B MTs N Kudus dapat meningkatkan kemampuan komunikasi matematika peserta didik.

\section{Saran}

1. Pembelajaran dengan model cooperative learning tipe JIGSAW berbantuan kartu masalah perlu dilaksanakan dalam pembelajaran matematika di kelas, karena model pembelajaran tersebut dapat meningkatkan kemampuan komunikasi matematika peserta didik.

2. Guru dapat menggunakan kartu masalah sebagai alat untuk menarik perhatian peserta didik.

\section{DAFTAR PUSTAKA}

Anitah, S. 2010. Media Pembelajaran. Surakarta : Yuma Pustaka.

Arends, R. I., 2008. Learning to Teach (buku dua). Yogyakarta: Pustaka Pelajar.

Asaniah, S. 2004. Analisis Respon Peserta didik pada Tes Tingkat Perkembangan Berpikir Geometri Menurut Van Hiele Pokok Bahasan Jajargenjang, Belahketupat, Layang-layang, dan Trapesium Peserta didik Kelas II Semester Gasal SLTP Negeri 1 Wonosegoro Kabupaten Boyolali Tahun Pelajaran 2003/2004. Skripsi. Tidak diterbitkan. UNNES

Asikin, M. 2001. Komunikasi Matematika dalam RME. Disajikan dalam seminar nasional Realistic Mathematics Education (RME). Di Universitas Sanata Darma yogyakarta 14-15 November 2001.

Asikin, M. 2003. Mengembangkan Rubrik Skoring Komunikasi Matematika. Disajikan pada seminar nasional pendidikan matematika di Universitas Sanata Darma Yogyakarta 28-29 Maret 2003.

Budiarsih, R. 2007. Keefektifan Pembelajaran Kooperatif tipe JIGSAW berbantuan MoD (Math on Display) untuk meningkatkan aktivitas dan hasil belajar materi geometri siswa kelas VII. Tesis. Semarang : PPs Unnes.

Haetami.,A. \& Supriadi. 2008 Penerapan Model Pembelajaran Kooperatif Tipe JIGSAW untuk Meningkatkan Aktivitas dan Hasil Belajar Siswa pada Materi Kelarutan dan Hasil Kali Kelarutan. Jurnal Universitas Haluoleo.

Johnson, et al. 2000. Cooperative Learning Methods: A Meta-Analysis. University of Minnesota. 
Depdikbud. 1999. Bahan Pelatihan : Penelitian Tindakan Kelas (Action Research). Departemen Pendidikan dan Kebudayaan. Direktorat Jenderal Pendidikan Dasar dan Menengah.

Depdiknas. 2006. Standar Kompetensi dan Kompetensi Dasar dalam KTSP mata pelajaran matematika Sekolah Menengah Pertama/Madrasah Tsanawiyah. Jakarta : Depdiknas.

Johnson, D.W., Johnson, R.T. \& Holubec, E.J. 1994. Cooperative Learning in the Classroom. VA: Association for Supervision and Curriculum Development.

Johnson, et al. 2000. Cooperative Learning Methods: A Meta-Analysis. University of Minnesota.

Joyce, B \& Weil, M. 1994 Model of Teaching. Second Edition. Prentice-Hall International, Inc.

Kwang, T.S. 2002. An Investigative Approach to Mathematics Teaching and Learning. The Mathematics Educator, Vol. 6, No.2, 32-46.

National Council of Teachers of Mathematics (NCTM). (2000). Principles and standards for teaching school mathematics. Reston, VA: Author.

Program for International Students Achievement 2006. U.S : Department of Education. Tersedia di www.pisa.oecd.org. Diunduh 12 Januari 2008.

Schoenfeld, A. 2001. Purposes \& Methods of Research in Mathematics Education. Boston : Kluwer Academic Publisher, Vol.VII Page 22-276.

Slavin, R. E. 2010. Cooperative Learning: Teori, Riset, dan Praktik. Bandung: Nusa Media

Soeharto, K. 1995. Komunikasi Pembelajaran. Surabaya: SIC.

Soedjadi, R. 1999. Kiat Pendidikan Matematika di Indonesia (konstatasi keadaan masa kini menuju harapan masa depan). Depdiknas : Jakarta.

Suparno, S. 2001. Membangun Kompetensi Belajar. Direktorat Jenderal Pendidikan Tinggi. Departemen Pendidikan Nasional. Jakarta.

Sumarmo, U. 2003. Makalah Pembelajaran Matematika untuk Mendukung Pelaksanaan Kurikulum Berbasis Kompetensi. Bandung : UPI.

Tim PPPG Matematika Yogyakarta. 2005. Materi Pembinaan Matematika SMP di Daerah. Yogyakarta : Depdiknas.

Trends in International Mathematics and Science Study 2007. The International Association for the Evaluation Achievement Washington DC: American Institute for Reseach. Tersedia di http://timss.bc.edu/. Diunduh 30 Januari 2008. 
Trianto, 2009. Mendesain Model Pembelajaran Inovatif Progresif. Jakarta : Kencana.

Wijayanti, K. 2009. Peningkatan Hasil Belajar Mahasiswa pada Mata Kuliah Aljabar Linear Elementer II melalui Pembelajaran Kooperatif Tipe JIGSAW. Prosiding Seminar Nasional V Jurusan Matematika Universitas Negeri Semarang. 